\title{
Gender in sustainable entrepreneurship: evidence from the UK
}

\author{
Georgios Outsios \\ The Business School, Edinburgh Napier University, Edinburgh, UK \\ Seemab Ara Farooqi \\ Stirling Management School, University of Stirling, Stirling, UK
}

\begin{abstract}
Purpose - Existing research highlights gender as an important dimension for entrepreneurship theory and practice. This study aims to explore the differences between female and male sustainable entrepreneurs in the areas of previous professional experiences, their performance and growth, their use of financial resources and their overall attitude to risk.

Design/methodology/approach - Through a feminist perspective and on the basis of empirical evidence gathered through a series of 20 in-depth, semi-structured interviews with male and female sustainable entrepreneurs in the UK, thr authors analyse differences between male and female sustainable entrepreneurs.

Findings - The findings suggest that female role models play a significant role in the emergence of women sustainable entrepreneurs who start from the same experience levels as men, show strong feminist attitudes and are conscious of their contribution to global sustainability. Sustainable entrepreneurship offers women professional development and a limited flexibility to balance work and family commitments. Lack of funding appears to be a major constraint applying to both female and male participants, while the authors argue that business pragmatism in a difficult investment environment triggered women's reluctance to take on debt. Nonetheless, female sustainable entrepreneurs were found to have developed and used their professional and social networks to a greater extent than their male counterparts.

Originality/value - This study offers a new gender perspective to the research of sustainable entrepreneurship and, at the same time, contributes with findings from research on sustainable entrepreneurs to the study of gender in management.
\end{abstract}

Keywords - Performance and growth, Social networks, Role models, Backgrounds, Financial resources, Gender differences in sustainable entrepreneurship

Note: This is the Author's accepted manuscript and is not the version of record. The version of record is available at: http://www.emeraldinsight.com/doi/abs/10.1108/GM-12-2015-0111

Please cite as:

Outsios, G and Farooqi, SA (2017) "Gender in sustainable entrepreneurship: evidence from the UK", Gender in Management: An International Journal, Vol. 32 Issue 3, pp.183-202. 


\section{Introduction: Gender in entrepreneurship and sustainable entrepreneurship}

Entrepreneurship remains a cornerstone for economic development, hence policymakers' focus on ways to foster it among underrepresented groups of the entrepreneurial population (European Commission, 2003). Sustainable entrepreneurship is a newly emerging research field, also subject to increasing policymaking interest (Shaw and Carter, 2007; Meek et al., 2010). According to research (e.g. Carter and Rosa, 1998; Marlow, 2002; Marlow and Patton, 2005), perceived gendered characteristics may have a negative impact on women who choose an entrepreneurial career.

Sustainable entrepreneurship has emerged as an overlapping research and practice area between sustainable development and entrepreneurship (Cohen and Winn, 2007). Sustainable development refers to "development that meets the needs of the present generation without compromising the ability of future generations to meet their needs" (WECD, 1987: 43). Since the agreement on guidelines for sustainable development by the United Nations (WCED, 1987) and the introduction of the triple bottom line, a management framework for financial, environmental and social sustainability by Elkington (1994), research has evolved from organisational greening (the adaptation of enterprises for more sustainable operation) in the 1990s, towards a more radical, sustainable entrepreneurship. We adhere to Dean and McMullen's paradigm, who define sustainable entrepreneurship as "the process of discovering, evaluating, and exploiting economic opportunities that are present in market failures which detract from sustainability, including those that are environmentally relevant" (2007:58).

Although research in sustainable entrepreneurship has focused on a wide spectrum of themes, it has thus far overlooked the role of gender (Hall et al., 2010; Thompson et al., 2011). We contribute to addressing this research gap by exploring similarities and differences in the 
experiences of male and female sustainable entrepreneurs in the UK. We do so through an analysis of twenty in-depth interviews with ten female and ten male sustainable entrepreneurs in the UK sociocultural and business context. Through a social constructionist feminist perspective we aim to explore the differences between female and male sustainable entrepreneurs in the areas of (a) previous professional experiences, (b) their performance and growth, (c) their use of financial resources and overall attitude to risk.

The special issue of the Journal of Business Venturing (2010) urged researchers to investigate the conditions and motives of sustainable entrepreneurs. Yet, despite the growing interest in sustainable entrepreneurship at academic and policymaking levels, little is known about how gender influences the initiation and development of sustainable enterprises, or how gender specific barriers found in conventional enterprises prevent or compromise the emergence of female sustainable entrepreneurs, which constitutes an important manifestation of women's overall contribution in global sustainability.

We first (Section 2) evaluate research on the role of gender in entrepreneurship and highlight the gap related to the absence of gender themes in sustainable entrepreneurship research, while also defining our perspective on the topic of gender in sustainable entrepreneurship. We then outline our research methodology (Section 3) and we dedicate the subsequent sections to the analysis of our findings (Section 4) and the key findings and conclusions (Section 5). Section 6 analyses the implications of our findings for theory and practice, and Section 7 highlights our study's limitations along with the opportunities for future research.

\section{Framing research on gender in entrepreneurship}

There is a general research consensus that gender plays a complex and significant role in the entrepreneurial process (Gupta et al., 2009). Although literature does not suggest there is any fixed association between socialized gender and biological sex (Fischer et al., 1993; Fine, 
2010), gendered characteristics are employed as a sense-making apparatus (Marlow and Swail, 2014). This construct embodies the subordination of the feminine within the binary hierarchy through the male or female body (Buttner, 1993). According to Ahl and Marlow (2012), gender inequalities in power and status become deeply ingrained in society until they appear as normal and inevitable.

Feminist theory is broadly categorised into (a) Liberal Feminism, which considers men and women essentially similar, (b) Social Feminism, where men and women are viewed as fundamentally different, and (c) Social Constructionist Feminism, arguing that similarities and differences between men and women are socially constructed (Gilligan, 1982; Calás and Smircich, 1996). Our study does not make any prior assumptions about differences in men and women (Social Feminist), neither do we assume that they are alike (Liberal Feminist). We adopt a Social Constructionist Feminist approach and use the term gender as socially constructed for exploring similarities and differences in the experiences of male and female sustainable entrepreneurs in the UK.

As a social construction, gender can hinder women's access to and engagement with specific socio-economic contexts (Ahl, 2006; McRobbie, 2009). There is a tendency in entrepreneurship literature to ascribe entrepreneurial traits with masculine attributes, creating a hierarchy in which women appear to lack entrepreneurial potential, entrepreneurial traits, attitudes, and ambition (Bruni et al., 2004). Ahl (2006) notes that entrepreneurs are often described with masculine characteristics by stakeholders (e.g. policymakers), leaving women entrepreneurs invisible and unacknowledged. Entrepreneurship research appears to position masculinity as a norm, suggesting that a woman's entrepreneurial performance results from their own feminised deficits. Such a normative male model of entrepreneurial achievement places women entrepreneurs in a disadvantaged position (Marlow and Patton, 2005). 
Gender appears to play a significant role during the phases of pre-start up, start up, and growth (Rosa et al., 1996; Boden and Nucci, 2000; Minniti et al., 2005) and is recognised as a key attribute influencing the overall experience and performance of entrepreneurs (Rosa et al., 1996). Gender differences in motivation, preferences, and expectations explain the low engagement of women in entrepreneurship (Fielden et al., 2003; Sarri and Trihopoulou, 2005).

Early research by Birley (1989) showed that the emerging gender differences stem from changing roles in society, rather than intrinsic motivational and skill differences. Later, Cowling and Taylor (2001) found gender related differences in educational background, with female entrepreneurs being the better educated, but with male entrepreneurs having a better prospect of surviving and growing their enterprise. Shaw et al. (2001) identified pre-entry and entry barriers specifically experienced by female entrepreneurs and located them in hard resources such as finance and assets, as well as in soft resources such as management experience, training and networking. Overall, research on gender in entrepreneurship is dominated by quantitative studies which tend to present contradictory results and do not allow the development of conclusions for subdomains such sustainable entrepreneurship without in-depth research.

\section{Gender differences in professional backgrounds}

Eastwood (2004) highlights that women, compared to men, lack experience of the labour market and critically examines the traditional view of gender roles, the financing of ventures started by women and the use of networking as a result of women's under-representation in higher management positions. Additionally, Eastwood (2004) listed the lack of knowledge and training in management and IT related skills and low self-perception as barriers for female entrepreneurs. Nonetheless, Carter et al. (2001) argue that women turn to entrepreneurship for greater flexibility to balance their professional aspirations and family 
commitments, a view confirmed by other studies (Aldrich and Cliff, 2003; Eastwood, 2004; De Bruin et al., 2006). Nonetheless, this flexibility could hinder the performance and growth of the business (Eastwood, 2004).

Carter and Rosa (1998) caution researchers focusing on gender in entrepreneurship that a preliminary data assessment may indicate minor gender specific variations among entrepreneurs, but an in-depth analysis may reveal significant "qualitative" differences in the levels of start-up capital and in the access of finance. Although financial barriers for female entrepreneurs has been an important topic in regional entrepreneurship research (Shane et al., 1991), Carter et al., (2007) found no substantial evidence to support the notion of discrimination by UK bank officers against female entrepreneurs.

\section{Risk assessment and the finance of female and male enterprises}

Research on gender and access to finance reveals conflicting results (Carter and Allen, 1997; Brush et al., 2006). The European Commission Observatory of SMEs (2003) concluded that the lack of bank loans for female entrepreneurs is due to women's tendency to ask for lower sums, which leaves a smaller profit margin for the banks. Expectations, initial motives, opportunities sought and business types show gender related variations, and these influence the type of the enterprise. Such observations should be taken into account when comparing the outcomes of ventures across genders (Office of Advocacy, 2007). Evidence on entrepreneurial finance suggests that women face challenges in accessing finance and have a propensity to establish their enterprise in low growth sectors (Coleman, 2000); these constraints are attributed to structural and gender differences (De Bruin et al., 2006).

Research highlights risk as one of the factors which poses a challenge to female entrepreneurs, who were found to be more risk averse than their males counterparts (Sexton, 1989a; Chung, 1998; Slovic, 2000; Jianakopoulos and Bernasek, 1998). Female entrepreneurs were found to have lower risk propensity scores than male entrepreneurs on a psychological 
scale (Sexton and Bowman-Upton, 1990). This risk aversion renders women less willing to trade potential gain for risk, leading them to business type choices with lower failure probabilities compared to men (Brush et al., 2006). A similar finding was reported by Sexton and Bowman-Upton, who reflect that female entrepreneurs are "less willing to get involved in situations with uncertain outcomes where financial gain is involved" (1990:34).

Gender variations towards risk are associated with divergences in cognitive abilities, as men and women gather information and solve problems differently (Barrett, 1995; Gatewood et al., 1995; Chung, 1998). Eckel and Grossman (2003) concluded that women search for more information on how to reduce the potential risk in a business opportunity. Others have attributed the risk aversion propensity of women to their 'caring and nurturing' role which inhibits risk taking and promotes risk avoidance attitude, reinforcing the norms which prevail in contemporary society in relation to women (Kepler and Shane, 2007). Beaver (2002) linked female entrepreneurs' risk aversion attitude to the process of socialisation and other deeper psychological factors. Cumulatively, gender socialisation, prior experiences, cognitive cues and a bias portraying women as 'risk averse' position women as a structurally disadvantaged group, lacking in masculine traits reflected in the normative male entrepreneurial model (Marlow and Swail, 2014).

\section{Performance and growth}

Gender differences were also identified in enterprise performance and growth. Although it has been argued (e.g. Sexton, 1989b) that there are no psychological inhibitions for women expanding their SMEs, Anna et al. (2000) suggest that women's perception of their abilities and the balance of family and work can influence their business growth (Aldrich and Cliff, 2003; Eastwood, 2004; De Bruin et al., 2006). Furthermore, Cliff (1998) argued that women who are less experienced on a management level fail to grow their business effectively and thus limit the potential of their business. The growth of female enterprises is also hindered by 
a "belief that fast paced expansion will place inordinate demand on the entrepreneur's time and energy" (Cliff, 1998: 535).

Studies (e.g. Roomi et al., 2009) have identified financial, human and social resources, technical and managerial skills, the potential to develop staff, and opportunity recognition as factors which influence growth. The literature suggests that social norms about the role of women in society, a lack of female role models, and the balance of commitments between family and work become entry and growth barriers for female entrepreneurs (Stoner et al., 1990). In particular, the attitudes towards the role of women make it more difficult for female entrepreneurs to gain support for their entrepreneurial activities from their family and friends (Stoner et al., 1990; Brush, 2004). Additionally, the relative shortage of female entrepreneurs as role models renders mentorship in the start-up and growth stages more difficult for female entrepreneurs.

\subsection{Gender and motivation}

Research on the motives behind business start-ups suggests that women are driven by the desire to achieve balance between work and family, as self-employment often allows them a more flexible work schedule (Boden, 1996, 1999; Carter et al., 2007; Brush et al., 2006; De Martino and Barbato, 2003; Lombard, 2001) for family, and specifically for childcare (Boden, 1996; Connelly, 1992). In contrast, research indicates that for male entrepreneurs the achievement of developing a company and the financial gains were more significant factors in setting up an enterprise (Borooah et al., 1997; De Martino and Barbato, 2003; Wilson et $a l ., 2004)$. For some the portrayal of women as 'caring and relational' turns this disadvantage into an advantage, an opportunity to fulfil goals in their personal and professional life (Carter and Allen, 1997). However, Ahl (2006) suggests that this view of female motivation supports the male normative model. 
Recent studies have also investigated gender differences in sustainability attitudes, behaviours and activities (e.g. Braun, 2010; Hechavarria et al., 2012). Braun (2010) approached business sustainability from a gender perspective and analysed the difference in attitudes and behaviour in the Australian context. The study concluded that the greening process of ventures run by women is driven by broader ethical concerns regarding sustainability to a higher degree compared to their male counterparts. Organisational greening has been conceptualised as the adaptation of existing businesses to sustainable and environmentally friendly processes (Harris and Crane, 2002).

Organisational greening and corporate social responsibility (CSR) have been key themes of the sustainability research agenda since the nineties (e.g. Shrivastava, 1994; Buchholz, 1993) and have been the subject of research, acclaim and criticism (e.g. Hart and Milstein, 1999; Hall and Vredenburg, 2003). In our study, we contribute to the sustainability research agenda with gender specific findings not on the greening of existing ventures, as in the case of Braun (2010), but on the founding of sustainable enterprises which offer new sustainable services and products from the start.

Overall, despite the continuously emerging volume of research on the role of gender in entrepreneurship, investigating the background, performance and growth even in new sectors such as in rural tourism entrepreneurship (e.g. Pettersson and Heldt, 2014), research on sustainable entrepreneurs lacks a gender perspective. We have found that research in sustainable business start-ups has to date widely neglected gender as a factor or dimension in the analysis. Remaining questions about gender differences in the conditions surrounding the emergence of sustainable entrepreneurs constitute a significant research gap. Through a qualitative research design, outlined in the next section, we shed light on gender specific differences in professional backgrounds, performance and growth of sustainable entrepreneurs. 


\section{Methodology and sampling frames}

Our research explores the similarities and differences of twenty male and female sustainable entrepreneurs, and is guided by a social constructivist epistemology, reflecting that our knowledge on the topic can be expanded with the analysis of entrepreneurs' background and experiences. The chosen research approach gives prime importance to the social construction of the phenomenon from the informants' point of view (Bryman, 2001). The data was collected through in-depth, semi-structured interviews with a total of twenty (ten female and ten male) UK environmental entrepreneurs (Table 1).

\section{INSERT TABLE 1 HERE}

In accordance with Dean and McMullen's (2007) seminal study, we sampled sustainable entrepreneurs as an inclusive term encompassing environmental and social entrepreneurs. We used data bases such as Fame, offered by the Van Dijk Bureau, and the Dun and Bradstreet catalogue. We identified our participants as founders of enterprises (up to 249 employees) which supply the market with sustainable products or services. All interviews were conducted face to face (in three cases via Skype) and lasted approximately fifty minutes each.

Grounding our research in the naturalistic paradigm, we have inductively analysed our data adhering to the principles developed by Lincoln and Guba (1985) and Corbin and Strauss (1990) in order to establish the rigour of the research process. Initially, we developed our first order codes through an open coding process relying on the words and phrases as spoken by the informant (Corbin \& Strauss, 1990). Subsequently, we used axial coding to make connections between categories and sub-categories as developed in our first round of open coding. Throughout this process we relied on constant comparison techniques in order to develop connections and put similar categories together under theoretically derived 
aggregated themes (Corbin \& Strauss, 1990; Gioia et al., 2013). We engaged in developing aggregated themes until no new patterns were emerging from the data. Overall, we analyse three broad themes, (a) professional backgrounds, (b) feminist influences and attitudes and (c) the finance, performance and growth of sustainable enterprises.

\section{Analysis of the role of gender in sustainable entrepreneurship}

Our analysis and findings are structured in accordance to the themes reviewed in the evaluation of existing literature (Section 2). Specifically, we focus our analysis on the professional background of our interviewees, where we find similarities in the quality and level of experiences, while we analyse the unique role of third sector experiences. In feminist influences and attitudes (Section 4.2) we analyse our findings on women's empowerment in the context of sustainable enterprises. Our analysis' last section is dedicated to gender similarities and differences in the performance and growth of a sustainable enterprise.

\section{Professional background}

Our interview findings confirm that the professional background of both male and female sustainable entrepreneurs played a significant role in their emergence. Although extant research (e.g. Eastwood, 2004) portrays female entrepreneurs as lacking previous professional experiences compared to their male counterparts, we found female sustainable entrepreneurs possessed a similar level of experience as they started their enterprises. In the context of sustainable entrepreneurship, we found that previous professional experience in the third sector (e.g. NGOs, charities) particularly influenced the later sustainable entrepreneurial development of our participants. As one female respondent explained:

"My background, I'm an accountant by trade and I've worked in the voluntary sector nearly all of my working life. I have worked for a long time for housing associations but then I came up to Scotland and worked at the Scottish Council of Voluntary Organisations and have been here for three years." (F-10) 
The theme of previous work experiences with the third sector has been a consistent reference point for our interviewees. Another female entrepreneur in the waste management sector reflected how working for a charity helped her develop vocational business skills (e.g. fund raising, cash flow management, HRM) and instilled the values which ultimately influenced her in setting up a sustainable enterprise:

"My environmental passion mainly came through peers and through friends and through working for a charitable organisation that highlighted those values. Equally my experience of setting up a project, of constituting an organisation, of going and getting the funding, of then learning how to generate the income through running it.” (F-8)

Our findings from contemporary sustainable entrepreneurs contradict the dominant view of women entrepreneurs in entrepreneurship research of previous decades, which portrays them as underskilled and less experienced and educated than men (Hisrich and Bursh, 1984; Birley, 1989; Eastwood, 2004). Female sustainable entrepreneurs in our study are suitably experienced in vocational business skills and affluent in professional experiences. Another female entrepreneur reflects on the importance of accounting skills acquired from a previous role:

"I was the treasurer of the students association and that's when I realised the understanding of finance was key and that's why I trained as an accountant and then to be able to take that understanding of finances and that to other organisations." (F-10)

Although female sustainable entrepreneurs appeared more skilled and experienced than findings in entrepreneurship research suggest, the role of previous professional experiences remains highly significant in their development, especially for female entrepreneurs and the effect on their self-confidence and self-efficacy (Krueger and Brazeal, 1994). As a direct 
result of the quality of their professional experiences, the responses of female entrepreneurs showed confidence in their abilities. Indicatively, the female founder of a carbon offset enterprise recalls of her professional background:

"At the university I was the environmental officer, so as long as I can remember I cared about this sort of stuff. I think my realisation that I wanted to set something up on my own came about after I worked in strategy consulting for a few years and then took a year out to go run a charity in Zambia and that was exciting and difficult in equal measure as well. I realised then that I really liked running a small organisation and wanted to do something on my own when I got back. So that was the catalyst." (F-9)

The backgrounds of the female respondents include a wide spectrum of professional experiences from accounting, to consultancy and upper management. The richness and versatility of those experiences contradict the perceptions that experience-wise women entrepreneurs start their businesses from a disadvantaged position compared to men. Likewise, male interviewees also explained how previous work helped them found a sustainable enterprise. A male participant from the north of Scotland reflects:

"My background, to give you an idea, I've sat on various other boards, housing associations and such like, possibly gave me the skills to think a little bit more entrepreneurial about my approach, but my background has been in both the environment, in design, and in retail. So, I think they all snowballed together." $(\mathrm{M}-8)$

The role of previous experiences in the third sector has emerged among male participants as well. It appears as a key background commonality for both male and female entrepreneurs who moved from the not-for-profit (Charities, NGOs) sector to the "more-than-profit" (term used by Ridley-Duff and Bull, 2011), founding sustainable enterprises. 
"Going back to the start, my background is in social care and social work, so it's very much social I suppose. I come from what I would say disadvantaged background myself. In my 30's, I trained and I became a social worker, worked for 10-12 years in Glasgow, the council there, the voluntary sector and a couple of charities.” (M-9)

One notable difference between male and female participants in our study was the use of professional and social networks. In our research, the cases of F-2, F-6 and F-8 constitute examples of female sustainable entrepreneurs wealthy in social capital and networking. F-2 is a member of the entrepreneurs' panel of the Secretary of State for Business. We found female entrepreneurs $(8,9$ and 10) who not only hold leading positions in single gender networks, but in networks for entrepreneurs of both genders. Female sustainable entrepreneurs appear to appreciate the value of and use their social networks more than their male counterparts. Our findings from the UK sustainable entrepreneurship context contradict earlier research in gender and entrepreneurship which argue that women entrepreneurs lack social networking skills compared to men (Birley, 1985; Shaw et al., 2001; Eastwood, 2004). This variation in our findings with earlier research could stem from efforts to improve the role of women in business networks, while it could also relate to the sustainable aspect of the networks or the sustainable objectives of the participants in our study.

Overall, our analysis of the professional backgrounds of the study's participants highlighted that (a) female sustainable entrepreneurs are similarly experienced to their male counterparts and that (b) previous work experiences in the third sector have played a crucial role in the development of sustainable entrepreneurs of both genders. The third sector appears to be an incubator for the development of sustainable entrepreneurs in terms of (a) a sustainable mindset and (b) an entrepreneurial skill-set. As gender specific aspects, we identify a more profound significance female respondents attach to their previous work experience in relation to their 
entrepreneurial development, along with significant wealth in and use of professional and social networks.

\section{Feminist influences and attitudes}

The theme of women's empowerment and their role in entrepreneurship consistently emerged during our interviews with female participants. Extant research links family background and role models to future entrepreneurial action for both genders (Shapero and Sokol, 1982; Krueger, 1993; Bosma et al., 2012). In our study, female role models from the family milieu appeared to play a particular role and carry a special significance for female interviewees. A closer examination of the reflective account on the subject by a female respondent, based in the southeast UK, reveals the significance and empowering effect of a female role model; in her case a role model from the immediate family:

"My grandmother is probably the biggest role model in my life. She was a school teacher, but she was a legend. She was a single parent and raised her two daughters as a single woman in the 1950s in Canada. She was a legendary figure and a true matriarch, which we don't see that often and she had several grandchildren that were all very deeply inspired by the life that she lead and the work ethic that she had to her family and community and the children she taught. She was an incredible human being." (F-6)

This supports the notion that role models need not be entrepreneurs to inspire female empowerment, which can also lead to female entrepreneurship. Another participant provides a closer link to the subject through an illustrative insight into the reasons women enter sustainable entrepreneurship, linking the process to an important theme in female entrepreneurship literature: the masculine characteristics associated with the traditional view of entrepreneurs (Ahl, 2006; Ahl and Marlow, 2012; Marlow and Swail, 2014) with sustainable entrepreneurship: 
"Women are more liable to have confidence in their abilities when it is not solely commercial. People who are successful in the commercial world exhibit what have been traditionally known as masculine characteristics, kind of aggressiveness and ambition. I'm not saying that they are necessarily masculine characteristic, but they're widely thought of as that. So with sustainable enterprises it is maybe that women are more confident in their ability to deliver social and environmental goods, as well as the profitability of financial sustainability." (F-9)

This account portrays sustainable entrepreneurship as a field where women challenge stereotypical perceptions in and about entrepreneurship. According to our female respondents, the environmental and social objectives entailed in sustainable entrepreneurship empower women's confidence. Additionally, we also discovered several sustainable enterprises started by women were aimed specifically at female customers. But this phenomenon can also include a deeper meaning and reignite the debate on gender differences in sustainability behaviour (see Davidson and Freudenburg, 1996) among men and women, as well as the available options to them respectively. One such enterprise was created by an entrepreneur in media and fashion retail.

"The whole thing started from me getting women to be greener, to have greener shops and customers. Since I had the idea in 2006, we've changed so much, back then it did seem a bit weird." (F-3)

Three of the female sustainable entrepreneurs interviewed set objectives to promote sustainable services and products exclusively to a female clientele. This forms another gender specific finding, as although we actively searched, we did not identify any male sustainable entrepreneur aiming to offer sustainable alternative products (e.g. male fashion) and services explicitly for and to men. 


\section{Performance and growth of the sustainable enterprise}

We next focus our analysis on findings regarding our interviewees' experiences with performance and growth. Literature suggests that there are gender differences in the overall performance and growth of enterprises as men and women differ significantly in the levels of financial resources they employ and their overall attitudes towards growth (Carter and Cannon, 1988; Carter, 2000; Calás et al., 2009). There are also suggestions that family commitments can undermine the performance and growth prospects of female founded enterprises (Eastwood, 2004).

In the context of sustainable entrepreneurs we examine different attitudes towards growth and performance, and we further investigate (a) the role of family commitments in female sustainable entrepreneurs and (b) the use of financial resources, two subthemes directly related to performance and growth. Our first finding relates to the perception of growth among our participants. We encountered cautious attitudes by both male and female participants who were eager to discuss their objections on the prospect of growth. Indicatively, the award-winning female founder of one of UK's most innovative sustainable enterprises opines:

"If your business is not a sustainable business, then obviously growth is really bad for the environment. But once you've got the right business model, one that is actually symbiotic and good for the planet, then there is no conflict. Actually it is much better if you do grow, because the more you grow, the less waste will go to landfield and the more charities we'll be able to support through our donations." $(\mathrm{F}-1)$

Furthermore, another female interviewee expressed a more cautious view of the meaning of growth in the context of sustainable enterprises.

"Something we can do on an ongoing basis without making any further changes to what we're doing, and it doesn't just imply growth. There is big pressure even 
on sustainable enterprises to grow, but we would rather concentrate on doing what we do better, but on the same scale, because the scale is sustainable. Sustainable in the sense that we can keep doing what we want to do without changing anything." (F-8)

A male participant offered an insight into the ethical and strategic dilemmas involved in the process of growth for sustainable enterprises.

"We will do things that other companies will not do and that is a very valuable thing to our clients. I believe as we move forward and as we grow that, personally and our board and anyone else who I bring into the organisation will replicate those values and will continue that. But that is a challenge because the bigger you get, that brings in challenges of management and scope of control. But I believe we can do it." (M-3)

Our first finding on the performance and growth of sustainable enterprises relates to a cautious, but also conscious approach to enterprise growth. Unlike extant entrepreneurship research (e.g. Stoner et al., 1990), we find that cautiousness towards business growth is not limited to female respondents, nor did female participants appeared more reluctant in growing their enterprises than their male counterparts. Both female and male sustainable entrepreneurs appeared positive about the prospect of growing their enterprise, but cautious about the effect on the environment and the sustainability of their business. Their cautious attitudes stem not from gendered characteristics or perceptions about their role in society and business or family commitments, but from the ethical concerns regarding the compatibility of sustainability and growth, or sustainable growth. It appears that there are ethical, as well as strategic dilemmas and challenges in maintaining the sustainable nature of the enterprise while growing. 


\section{Family commitments}

As reviewed in section 2.4, a timeless gender specific topic in contemporary entrepreneurship literature has been the link between setting up an enterprise and family commitments. Seminal studies such as that by Marlow (1997) support the notion that one of the reasons female entrepreneurs enter the entrepreneurial process is to balance family commitments and work. This aspect has been argued to act as a trigger as well as an obstacle for the growth of female-run enterprises (Bruin et al., 2007). In our study, the conditional flexibility conferred by self-employment emerged as a motive exclusively among female sustainable entrepreneurs. Indicatively, one female interviewee reflects:

"It is close enough to my family home that my children can come round because ultimately my business has to be sustainable for my family as well, has to work for them, so they can come round after school and hopefully they'll take an interest in the business long term.” (F-4)

Another female entrepreneur reveals how flexibility for childcare was a key motivation in setting up a sustainable enterprise. She explains personal arrangements and reflects on the meaning of women's empowerment as a mother and a female sustainable entrepreneur:

"I started up (because of) my childcare responsibilities, but I also set up the business so I can work remotely from home. I use drop-ship model so I don't have to pack and ship because it takes too much time. I work from home to keep costs low and so a lot of the way that I work is meant to make my life easier with children. So I think a lot of women find it empowering setting up their own business." (F-5)

It is unclear if and how childcare hinders the growth of sustainable enterprises and the potential impact on growth those commitments can have. Although the main argument is that the business vision and strategy are compromised by attempts to address family commitments, it is 
counterbalanced by the sense of flexibility and settlement they bring to the entrepreneur. Another female entrepreneur reflected on a different view of sustainability:

"One of the key motives for me to start this business and structure it the way it is today was to be able to work remotely at flexible hours and be able to assist my sister and parents any time they need me. My sister contributes to the business as well. This business has significant advantages for me, it has been a sustainable choice for me and my family as well." (F-3)

The last reflective account extends family commitments beyond childcare to senior care and other types of family support, and provides a new dimension to the subject. It also portrays sustainability as a reciprocal process, not simply conferring a positive balance to the environment, society and economy, but also bringing balance to the entrepreneurs' life. According to Eastwood (2004), the flexibility for family commitments can become a hurdle for the growth of the female owned enterprise. This can be the root of some growth problems that some of our female entrepreneurs have experienced in relation to improving their vocational business skills and their time management (Roomi et al., 2009).

\section{Financial resources}

The management of financial resources, including the process of raising the necessary startup and growth capital, constitutes a fundamental pillar of entrepreneurship. It is also an area where women were found to differ significantly from men and appear underfunded and less supported by financial institutions and their families (Carter and Rosa, 1998). Our interviews highlight experiences of overwhelming financial constraints, even among the most innovative and successful sustainable entrepreneurs. Specifically, we found access to capital a major obstacle for both start-up and growth stages, and financial institutions and governmental funding bodies reluctant to support sustainable entrepreneurs. A male interviewee, a serial sustainable entrepreneur and founder and retailer of one of the UK's leading natural organic 
cosmetics firm, reflects on the difficulty of raising financial capital for a sustainable enterprise:

"Cash, of course! No one helps you. There is no funding. The green banks never supported me in what I do. I do not think that there is anyone out there who is prepared to really take big risks on green things. So the green banks, I approached them three times in the past. Never once they helped, even though I preferred to go to a green or sustainable bank than the main banks. They may say they help green people, but they still got their criteria and if they think you are in a risk, they do not help." (M-4)

The cofounder of a sustainable taxi enterprise expressed his frustrations with financial resources available to sustainable businesses, also noting that the company was rejected for a loan by the same bank which later approached him to become their organisation's staff transportation partner:

"There is no funding available, for anything. So everything we have done has had to be funded by the company itself. We have had no grants, no cheap loans, no incentives, nothing. We opened a fully serviceable garage, with an eco-friendly paint booth which uses water-based paints and biodegradable stuff, low-energy lighting and heating. But again, we got no help for that, we had to do that with our own funds.” (M-1)

The use of personal and family funds to finance the start and growth of a sustainable enterprise was a common theme in our interviews. The analysis of reflective accounts portrays a rather pessimistic view of the UK's financial institutions and the funding available to sustainable entrepreneurs. This poses a significant barrier for their emergence, performance and growth, ultimately a key hindrance for promoting sustainability in the UK. Several participants perceived financial institutions as an unrealistic source of start-up or growth capital, in some cases explained as an effect of recession. The founder of one of UK's the most innovative energy enterprises reflects: 
"There is no way a bank would touch anything along our line until we have a customer base actually operating on at least a pre-commercial level. The banks are not a realistic resource for capital.” (M-2)

The situation and experiences in the early stages was similar for a female participant, founder and owner of a leading global environmental services enterprise based in Scotland. She recalls:

"We've had very little support from government or funding bodies. We've always just always had to do it by cash flow. We're better now but we still have hardly any funding, so we might be doing huge projects, but we have a very low overdraft because there is no support, really, given by banks and we don't want to go into someone owning our company either, to get big funding." (F-1)

The above accounts constitute a testimony of the practical difficulties sustainable entrepreneurs face in access to start-up and growth capital. Considering our research is based on interview data from SME entrepreneurs, the size of organisations was suggested as an important consideration when interpreting these experiences:

"Well, the major problem with any small company is cash flow; trying to generate enough cash flow to make life bearable and so on. I guess generating the clients is the most difficult thing. Once we got them, they love what we've got." $(\mathrm{M}-10)$

Female interviewees viewed the financial constraints they faced as systemic inhibitors (large conventional enterprises using their influence to divert funding away from sustainable entrepreneurship). The overall lack of funding for projects with sustainable objectives (e.g. research and business projects) and the post-recession years during which financial institutions maintained a limited and more cautious investment profile, were also identified as causes of financial challenges. Female interviewees particularly struggled with financial institutions: 
"I think funding is always an issue. When I started, I didn't know so I went and asked for a loan in a bank. Afterwards, I realised that is just not possible. They do not give loans unless you take on debt and personal debt and they don't usually fund sustainable projects. There is not much from private funds." (F-4)

The above account introduces a key theme in female entrepreneurship research, which relates to women entrepreneurs' risk aversion (Sexton, 1989a; Chung, 1998; Jianakopoulos and Bernasek, 1998). This characteristic was manifested in our interviewees through our female respondents' reluctance to take on debt. Specifically, an example of our female participants reluctance to take was a fashion entrepreneur:

"That is partly due to also my reluctance to take on debt as well. So at the moment I'm just keeping my business as it is rather than expanding, until things sort of loosen up a bit." (F-5)

Our results reflect severe financial constraints among sustainable entrepreneurs linked not to gender, but the questionable compatibility of the sustainable enterprises' objectives with the financial world and the post-recession investment landscape in the UK. Nonetheless, the documented risk aversion among our female interviewees, in addition to a lower rate (compared to male) of use of family funds and other gender-specific inhibitors (see Carter and Rosa, 1998; Marlow and Patton, 2005), increases financial pressure on female sustainable entrepreneurs. As a result the survival, success and growth of UK sustainable enterprises owned by women are financially more complex.

\section{Key findings and conclusions}

Through a social constructionist feminist perspective, we analysed interview data from a sample of twenty sustainable entrepreneurs in three specific areas where, according to existing literature in entrepreneurship research, male and female entrepreneurs differ. A common theme in the background of male and female participants, and a novel theme in 
entrepreneurship research, was the role of previous professional experiences in the third sector. We found that our sustainable entrepreneurs had a long history in voluntary projects, charities and NGOs, where they gained valuable business experience (finance management, HRM) and strengthened their sustainability values.

In contrast to existing global research (e.g. Eastwood, 2004) in conventional (nonsustainable) entrepreneurship, we found women entering sustainable entrepreneurship in the UK to have similar professional experiences (e.g. previous positions held, skills acquired, years of experience) to their male counterparts. This contradiction relates to the study's sociocultural context, the UK, and the country's long standing legacy of women in labour, entrepreneurship and power (i.e. female Royals, Prime Ministers, First Ministers and MPs). Nonetheless, we acknowledge that findings from different sociocultural and development (e.g. developing countries) contexts may document different findings.

The topic of female empowerment and feminist influences was one of the themes that stood out in our interviews with female participants. A novel manifestation of female empowerment is the sustainable enterprises started by women and aimed at a female consumer base. According to our analysis, the environmental and social objectives involved in sustainable entrepreneurship render it a more attractive business option for potential women entrepreneurs. In return, some female sustainable entrepreneurs make encouraging sustainable alternatives to women an aim of their business. Sustainable entrepreneurship appears to be a means for female (entrepreneurs and consumers) empowerment. Additionally, female entrepreneurs appeared to have been motivated towards entrepreneurship and sustainability by female role models.

Our interviewees' responses to questions related to growth indicate that weaknesses in areas such as raising capital have hindered the performance and the growth prospects of their 
enterprises. This demonstrates that factors identified by Rosa (1988), who highlighted limitations among UK entrepreneurs in business skills such as marketing, enterprising, raising capital for growth and human resource, are still relevant. We found that during the start-up stage mentoring and support from networks was an important contributor to the performance and survival of sustainable enterprises, and a valuable form of social capital. Despite the experience levels of the sustainable entrepreneurs interviewed, they faced strategic (e.g. vocational business skills in growing an enterprise, scarcity of financial resources for growth, market share) challenges, as well as ethical concerns in the prospect of growing their business.

Our interviews contain a plethora of reflective accounts on the scarcity of financial resources, but no evidence to support the development of a proposition or a hypothesis that there is gender discrimination in the available funds for sustainable entrepreneurs in the UK. The most commonly used financial resource during the start-up phase is personal savings and funds, while during growth stage it is capital generated by the business. Female and male entrepreneurs did not appear to differ in the management of their funds or the constraints they have experienced.

Although we support the notion by Humbert and Bridley (2008) that the debate on risk should not be limited to financial risk and lending, we found this to be the only difference between male and female sustainable entrepreneurs in the area of financial resources. On the other hand, it should be noted that both female and male interviewees portrayed financial institutions as risk-averse towards sustainable SMEs, our study's focus. Therefore, considering the characteristics of the post-recession investment landscape, collateral and other conditions for access to loans may have been unfeasible. As a result, we argue that our 
female respondents' reluctance to take on debt has not been triggered by a deeper psychological gendered trait, but by business pragmatism in a difficult investment environment. This lead the majority of our participants to the use of personal and family funds as start-up capital and the use of business generated income to sustain and grow the enterprise further.

Overall, the problematic relationship between sustainable entrepreneurs and financial institutions contradicts the UK policymaking goal to set the country as a global leader in sustainable entrepreneurship and innovation (Dyson, 2011). Several entrepreneurs of both types and genders were critical of the mission and structure of financial institutions. Their responses indicated a resignation and belief in the existence of a bias from funding bodies towards projects with sustainable objectives.

In conclusion, we found female sustainable entrepreneurs starting from the same experience levels as males to have strong feminist attitudes and consciousness of their contribution to global sustainability. Sustainable entrepreneurship offers women a unique opportunity and experience of professional development and a limited flexibility to balance work and family commitments. Lack of funding appears to be a major constraint affecting all entrepreneurs, while our argument that business pragmatism influences women's reluctance to take on debt is counterbalanced by an affluence of and more extensive use of networking compared to men.

\section{Implications for practice and theory}

Our study's conclusions on performance and growth support the significance of entrepreneurial training and specifically those focused on the development of vocational skills. We argue that relevant training needs to be customised according to the needs of 
participants (e.g. their skill-set, background, weaknesses) and maintain a contemporary agenda (e.g. changes and technicalities of regional legal frameworks, the contemporary investment landscape, the evolution of social media) to their training methods. By doing so, sustainable entrepreneurs can develop the skills that will allow them to address the strategic challenges of growing their enterprises, a process which can significantly increase their contribution to global sustainability.

Our results find particular application to the UK Green Investment Bank (GIB), set up by the UK Government with a goal to provide funding to sustainable enterprises. We support the notion that the GIB needs to establish and maintain a gender perspective in their investment policy. Specifically, the GIB needs to monitor data and performance of female sustainable enterprises and inform governmental bodies accordingly for the need of policy adjustments and new ways to stimulate female sustainable entrepreneurship.

From a theoretical perspective, we have contributed to existing debates on the role of previous professional experiences in entrepreneurship, the use of financial resources, family commitments and feminist influences and attitudes, providing data and conclusions from the context of contemporary sustainable enterprises. We have contributed to the timeless debate of vocational business skills, offering data from contemporary sustainable entrepreneurs, and highlighted unique sustainable specific ethical dilemmas in sustainable entrepreneurial growth. Furthermore, we have acknowledged and explored a novel theme and form of female empowerment in sustainable enterprises founded by female entrepreneurs, aimed specifically at female consumers.

A central theoretical implication stemming from the depth and diversity of our findings relates to gender, which remains a key dimension in founding a sustainable enterprise. We urge future research of sustainable entrepreneurs to incorporate gender as a variable and dimension in analyses. Overall, our study contributes to the emerging field of research in 
sustainable entrepreneurship by offering a new gender perspective and to gender in entrepreneurship research with empirical evidence and findings from the sustainable entrepreneurship subdomain. Finally, our findings on social capital and networks complement knowledge in the respective research fields.

\section{Research limitations and future research}

Our study is subject to limitations which should be considered when interpreting the results. As any exploratory study based on qualitative data and analysis, the results and conclusions have time and context limitations applied to them (Patton, 1980; Guba and Lincoln, 1989). Therefore, our findings are limited to the UK sociocultural and business context, during the postrecession years. Nevertheless, conclusions can still be useful as a sensitising framework for research in other countries and our findings could lead to the development of propositions and hypotheses for testing in the UK and internationally. International comparisons would be particularly constructive in identifying solutions to gender specific barriers in sustainable entrepreneurship. Expanding knowledge on the motivations and success rates of sustainable enterprises targeting female customers is also a topic where future research can confer significant contributions to theory and practice.

A significant area for gender research is mixed gender entrepreneurial teams (e.g. Godwin $e t$ al., 2006). Our study contained one female entrepreneur (F-7) who was part of a mixed gender sustainable entrepreneurial team, as a cofounder of a recycling enterprise based in Fife, Scotland. Our study's objectives and sample structure and our limited access to the male business partner could not support further focus on the dynamics of this specific team. Therefore, an unexplored area for theoretical contribution by future research is mixed gender sustainable entrepreneurial teams. Specifically, the dynamics and histories of those teams, the 
role of women in those teams, their differences compared to their male business partners, and their differences with women in mixed gender, non-sustainable entrepreneurial teams.

Finally, a theme not yet fully understood with significant practical implications where future research needs to expand knowledge, is the role of third sector experiences in the development of sustainable entrepreneurs. Research can highlight training opportunities and how to further stimulate sustainable entrepreneurship amongst members of charities and NGOs. The relationship between private banks and sustainable entrepreneurs is also an area that requires further research. There is a need to determine the potential existence of bias against sustainable entrepreneurs in the finance world and examine effective ways that private banks can become a realistic source of capital for sustainable entrepreneurs.

\section{Bibliography}

Ahl, H. (2006), "Why research on women entrepreneurs needs new directions", Entrepreneurship Theory and Practice, Vol.30 No.5, pp. 595-623.

Ahl, H. and Marlow, S. (2012), "Exploring the dynamics of gender, feminism and entrepreneurship: Advancing debate to escape a dead end?", Organization, Vol.19, pp. $543-562$.

Aldrich, H. and Cliff, J. (2003), "The pervasive effects of family on entrepreneurship: Toward a family embeddedness perspective", Journal of Business Venturing, Vol.18 No.5, pp. 573-596.

Anna, A.N., Chandler, G.N., Jansen, E., and Mero, N.P. (2000), "Women business owners in traditional and non-traditional industries", Journal of Business Venturing, Vol. 15 No.3, pp. 279-303. 
Barrett, M. (1995), "Feminist perspectives on learning for entrepreneurship: The view from small business", in Bygrave, W.D., Bird, B.J., Birley, S., Churchill, N.C., Hay, M., Keeley R.H. and Wetzel Jr, W.E. (Eds.), Frontiers of entrepreneurial research, Boston, Babson College, pp. 323-336.

Beaver, G. (2002), Small Business, Entrepreneurship and Enterprise Development, PrenticeHall, Englewood Cliffs, NJ.

Birley, S. (1985), "The role of networks in the entrepreneurial process", Journal of Business Venturing, Vol.1 No.1, pp. 107-117.

Birley, S. (1989), "Female entrepreneurs: are they really any different?”, Journal of Small Business Management, Vol.27 No.1, pp. 32-7.

Boden, R.J. (1996), "Gende and self-employment selection: An empirical assessment”, The Journal of Socio-Economics, Vol.25 No.6, pp. 671-682.

Boden, R.J. (1999), “Gender inequality in wage earning and female self-employment selection", The Journal of Socio-Economics, Vol.28 No.3, pp. 351-364.

Boden, R.J. and Nucci, A.R. (2000), “On the survival prospects of men's and women's new business ventures", Journal of Business Venturing, Vol.15 No.4, pp. 347-362.

Borooah, V.K., Collins, G., Hart, M. and MacNabb, A. (1997), "Women in business", in Deakins, D., Jennings, P. and Mason, C. (Eds.), Small Firms: Entrepreneurship in the Nineties, Paul Chapman Publishing, London. 
Bosma, N., Hessels, J., Schutjens, V., Van Praag, M., and Verheul, I. (2012), "Entrepreneurship and role models", Journal of Economic Psychology, Vol.33 No.2, pp. $410-424$.

Braun, P. (2010), “Going green: women entrepreneurs and the environment”, International Journal of Gender and Entrepreneurship, Vol.2 No.3, pp. 245-259.

Brush, C., Carter, N., Gatewood, E., Greene, P. and Hart, M. (2006), Growth-oriented Women Entrepreneurs and their Businesses: A Global Research Perspective, Edward Elgar, Cheltenham.

Brush, C., Carter, N., Gatewood, E., Greene, P. and Hart, M. (2004), Clearing the Hurdles: Women Building High-Growth Enterprises, New York: Financial Times/Prentice Hall.

Bruni, A., Gherardi, S. and Poggio, B. (2004), "Entrepreneur-mentality, gender and the study of women entrepreneurs", Journal of Organizational Change Management, Vol.17, pp. 256-268.

Bryman, A. (2001), Social Research Methods, Oxford Press, Oxford.

Buttner, E.H. (1993), "Female Entrepreneurs: How Far Have They Come?", Business Horizons. Vol. 36 No. 2, pp. 59-65.

Buchholz, R.A (1993), Principles of environmental management: Tbe greening of business, Englewood, Prentice-Hall. 
Calás, M. and Smircich, L. (1996), “From the woman's point of view: Feminist approaches to organization studies" in Clegg, S., Hardy, C. and Nord, W. (Eds.), Handbook of organization studies, London, Sage, pp. 218-257.

Calás, M.B., Smircich, L. and Bourne, K.A. (2009), "Extending the Boundaries: Reframing entrepreneurship as social change through feminist perspectives", Academy of Management Review, Vol. 34 No. 3, pp. 552-569.

Carter, N. and Allen, K. (1997), "Size-determinants of women-owned businesses: Choices or barriers to resources", Entrepreneurship and Regional Development, Vol. 9 No.3, pp. 211-220.

Carter, S. and Cannon, T. (1988), Female entrepreneurs: A study of female business owners, their motivations, experiences and strategies for success, London, Academic Press.

Carter, S. and Rosa, P. (1998), "The financing of male - and female - owned businesses", Entrepreneurship \& Regional Development, Vol. 10 No. 3, pp. 225-241.

Carter, S. (2000), "Improving the numbers and performance of women-owned businesses: some implications for training and advisory services", Education and Training, Vol. 42 No 4-5, pp. 326-333.

Carter, S.L., Anderson, S. and Shaw, E. (2001), “Women's business ownership: a review of the academic, popular and internet literature” Discussion paper, DTI Small Business Service Research Report. 
Carter, S., Shaw, E., Lam, W., and Wilson, F. (2007), “Gender, Entrepreneurship, and Bank Lending: The criteria and Processes used by Bank Loan officers in assessing applications”, Entrepreneurship Theory and Practice, Vol. 31 No. 3, pp. 427-444.

Chung, J.T. (1998), "Risk reduction in public accounting firms: are women more effective?", International Review of Women and Leadership, Vol. 4 No. 1, pp. 39-45.

Cliff, J. (1998), "Does One Size Fit All? Exploring the Relationship Between Attitudes Towards Growth, Gender, and Business Size”, Journal of Business Venturing, Vol. 13 No., pp. 523-542.

Cohen, B. and Winn, M.I. (2007), "Market Imperfections, Opportunity and Sustainable Entrepreneurship", Journal of Business Venturing, Vol.22 No.1, 29-49.

Coleman, S. (2000), "Access to capital and terms of credit: A comparison of men- and women-owned small businesses", Journal of Small Business Management, Vol. 38 No.3, pp. 37-52.

Connelly, R. (1992), “Self-Employment and Finding Childcare”, Demography, Vol. 29 No.1, pp. 17-29.

Corbin, J. and Strauss, A. (1990), "Grounded theory research: Procedures, canons and evaluative criteria", Qualitative Sociology, Vol. 13, pp. 3-21.

Cowling, M. and Taylor, M. (2001), "Entrepreneurial women and men: Two different species?", Small Business Economics, Vol. 16 No. 3, 167-175. 
Davidson, D. and Freudenburg, W.R. (1996), "Gender and Environmental Risk Concerns: A Review and Analysis of Available Research", Environment and Behaviour, Vol. 28, pp. 302-339.

Dean, T.J. and McMullen, J.S. (2007), Towards a theory of sustainable entrepreneurship: reducing environmental degradation through entrepreneurial action", Journal of Business Venturing Vol. 22 No. 1, pp. 50-76.

De Bruin, A., Brush, C. and Welter, F. (2006), "Introduction to the special issue: towards building cumulative knowledge on women's entrepreneurship", Entrepreneurship Theory and Practice, Vol. 30 No. 5, pp. 585-94.

De Bruin, A., Brush, C. and Welter, F. (2007), "Advancing a framework for coherent research on women's entrepreneurship", Entrepreneurship Theory and Practice, Vol. 31 No.3, pp. 323-339.

DeMartino, R. and Barbato, R. (2003), "Differences Between Women and Men MBA Entrepreneurs: Exploring Family Flexibility and Wealth Creation as Career Motivators", Journal of Business Venturing, Vol.18 No.3, pp. 815-832.

Dyson, J. (2011), In Anonymous, “New Support for Entrepreneurs to turbo change Uk's Clean Tech Sector", The Midlothian and East Lothian Chamber of Commerce Business Magazine, Issue 5, March 2011, pp. 28-29.

Eastwood, T. (2004), Women entrepreneurs issues and barriers, a regional, national and international perspective, St Albans, Exemplas Holdings Ltd. 
Eckel, C. and Grossman, P. (2002), "Sex Differences And Statistical Stereotyping In Attitudes Toward Financial Risk", Evolution and Human Behaviour, Vol. 23 No. 4, pp. 281-295.

European Commission (2003), "Entrepreneurship in Europe”, Green Paper, COM 27, European Commission, Brussels.

Elkington, J. (1994), “Towards the sustainable corporation: Win-win-win business strategies for sustainable development", California Management Review, Vol. 36, No. 2, pp. 90100.

Fielden, L.S., Davidson, J.M., Dawe, J.A. and Makin, J.P. (2003), "Factors inhibiting the economic growth of female owned small businesses in North West England", Journal of Small Business and Enterprise Development, Vol. 10 No. 2, pp. 152-66.

Fine, D.C. (2010), Delusions of gender: How our minds, society, and neurosexism create difference, New York, NY, Norton.

Fischer, E., Reuben, R., and Dyke, L. (1993), "A Theoretical Overview and Extension of Research on Sex, Gender, and Entrepreneurship," Journal of Business Venturing, Vol. 8, pp. $151-168$.

Gatewood, E.J., Shaver, K.G., and Gartner, W.B. (1995), “A longitudinal study of cognitive factors influencing start-up behaviours and success at venture creation", Journal of Business Venturing, Vol. 10 No. 5, pp. 371-391.

Godwin, L.N., Stevens, C.E., and Brenner, N.L. (2006), "Forced to play by the rules? Theorizing how mixed-sex founding teams benefit women entrepreneurs in male- 
dominated contexts", Entrepreneurship Theory and Practice, Vol 30 No. 5, pp. 623 642.

Gilligan, C. (1982), In a different voice, Harvard University Press, Cambridge, MA.

Gioia, D.A., Corley, K.G., and Hamilton, A.L. (2013), "Seeking qualitative rigor in inductive research notes on the gioia methodology", Organizational Research Methods, Vol. 16 No. 1, pp. 15-31.

Guba, G.E. and Lincoln, S.Y. (1989), Fourth generation evaluation, Newbury Park CA, Sage.

Gupta, V.K., Turban, D.B., Wasti, S.A. and Sikdar, A. (2009), "The role of gender stereotypes in perceptions of entrepreneurs and intentions to become an entrepreneur", Entrepreneurship Theory and Practice, Vol. 33 No. 2, pp. 397-417.

Hall, J. and Vredenburg, H. (2003), "The challenges of innovating for sustainable development", Sloan Management Review, Vol.45 No.1, pp. 61-69.

Hall J.K., Daneke, G.A. and Lenox, M.J. (2010), "Sustainable development and entrepreneurship: Past contributions and future directions", Journal of Business Venturing, Vol. 25 No. 5, pp. 439-448.

Hart, S. and Milstein, M. (1999), "Global Sustainability and the Creative destruction of Industries”, MIT Sloan Management Review, Vol. 41 No.1, pp. 23-33. 
Harris, L.C. and Crane, A. (2002), "The greening of organizational culture: Management views on the depths, degree and diffusion of change" Journal of Organizational Change Management, Vol. 15 No.3, pp. 214-234.

Hechavarria, D.M., Ingram, A., Justo, R. and Terjesen, S. (2012), “Are women more likely to purse social and environmental entrepreneurship", in Hughes, K. and Jennings, J. (Eds.), Global Women's entrepreneurship research: Diverse settings questions and approaches, Edward Elgar, pp. 135-151.

Hisrich, R.D. and Brush, C. (1984), "The woman entrepreneur: Management skills and business problems", Journal of Small Business Management, Vol. 22 No. 1, pp. 30-37.

Humbert, A.L. and Bridley, C. (2008), "Challenging the concept of risk in relation to women's entrepreneurship", Gender in Management: An International Journal, Vol. 30 No. 1, pp.2-25.

Jianakopoulos, N., and Bernasek, A. (1998), “Are Women More Risk Averse?”, Economic Inquiry, Vol. 36 No. 4, pp. 620-630.

Kelley D., Brush C., Herrington M., and Ali, M. (2015), Global Entrepreneurship Monitor: Special Report, Women's Entrepreneurship, Global Report, Global Entrepreneurship Research Association.

Kelan, E. (2009), Performing gender at work, Basingstoke, Palgrave Macmillan.

Kepler, E., and Shane, S. (2007), Are male and female entrepreneurs really that different?, US Small Business Administration, Office of Advocacy, Washington DC. 
Kirkwood, J. (2009), "Motivational factors in a push-pull theory of entrepreneurship", Gender in Management: An International Journal, Vol. 24 No. 5, pp. 346-364.

Krueger, N.F. (1993), “Growing up entrepreneurial? Some developmental consequences of early exposure to entrepreneurship", Paper presented at the Academy of Management, 1993.

Krueger, N.F. and Brazeal D.H., (1994), "Entrepreneurial potential and potential entrepreneurs", Entrepreneurship Theory and Practice, Vol. 18 No. 3, pp. 91-104.

Lincoln, Y.S. and Guba, E.G. (1985), "Naturalistic Inquiry”, Newbury Park CA, Sage.

Lombard, K. (2001), "Female Self-Employment and Demand for Flexible, Nonstandard Work Schedules", Economic Inquiry, Vol. 39 No. 2, pp. 214-237.

Marlow, S. (1997), "Self-employed women- new opportunities, old challenges?", Entrepreneurship and Regional Development, Vol. 9 No. 3, pp. 199-210.

Marlow, S. (2002), "Women and self-employment: A part of or apart from theoretical construct?", International Journal of Entrepreneurship and Innovation, Vol. 3 No. 2, pp. 83-91.

Marlow, S. and Patton, D. (2005), “All Credit to Men? Entrepreneurship, Finance, and Gender”, entrepreneurship Theory and Practice, Vol. 29 No. 6, pp.717-735.

Marlow, S. and Swail J. (2014), “Gender, risk and finance: Why can't a woman be more like a man?", Entrepreneurship and Regional Development, Vol. 26, pp. 80-96. 
McRobbie, A. (2009), The Aftermath of Feminism: Gender, Culture and Social Change, London, Sage.

Meek, W.R., Pacheco, DF. and York, G.F. (2010), "The impact of social norms on entrepreneurial action: Evidence from the environmental entrepreneurship context", Journal of Business Venturing, Vol.25 No.5, pp.493-509.

Minniti, M., Bygrave, W.D. and Autio, E. (2005), Global Entrepreneurship Monitor, Babson Park, Babson College.

Office of Advocacy, (2007), "Women in Business", Working paper, U.S. Small Business Administration.

Patton, M.Q. (1980), Qualitative evaluation methods, Beverly Hills, Sage.

Pettersson K. And Heldt S.C. (2014) "Women tourism entrepreneurs: doing gender on farms in Sweden", Gender in Management: An International Journal, Vol. 29 No. 8, pp.487504.

Ridley-Duff, R. and Bull M. (2011), Understanding Social Enterprise: Theory and Practice, London, Sage.

Roomi M.A., Harrison, P. and Beaumont-Kerridge, J. (2009), "Women-owned small and medium enterprises in England Analysis of factors influencing the growth process", Journal of Small Business and Enterprise Development, Vol. 16 No.2, pp. 270-288.

Rosa, P. (1988), "Barriers, optimal firm size and managerial factors: Are there fundamental constraints on growth?", Scottish Enterprise Foundation, Conference Paper Series No. $28 / 88$ 
Rosa, P., Carter, S., and Hamilton, D. (1996), "Gender as a determinant of small business performance: Insights from a British study”, Small Business Economics, Vol. 8 No. 4, pp. $463-478$.

Sarri, K. and Trihopoulou, A. (2005),"Female entrepreneurs' personal characteristics and motivation: a review of the Greek situation", Women in Management Review, Vol. 20 No. 1, pp. 24-36.

Sexton, D.L. (1989a), “Growth decisions and growth patterns of women-owned enterprises”, in Hagan, O. and Sexton, D. (Eds.), Women-owned Businesses, Praeger, New York, pp. 135-150.

Sexton, D.L. (1989b), "Research on women-owned businesses: current status and future directions", in Hagen, O., Rivchum, C. and Sexton, D.L. (Eds.), Women-owned Businesses, Praeger, New York, pp. 183-93.

Sexton, D. and Bowman-Upton, N. (1990), "Female and Male Entrepreneurs: Psychological Characteristics and Their Role in Gender-Related Discrimination", Journal of Business Venturing, Vol. 5 No.1, pp. 29-36.

Shapero, A. and Sokol, L. (1982), "Social dimensions of entrepreneurship", in Kent, C., Sexton, D.L., Vesper, K. (Eds.), The Encyclopaedia of Entrepreneurship, Englewood Cliffs, Prentice-Hall, pp. 72-90.

Shane, S., Kolvereid, L., and Westhead, P. (1991), "An exploratory examination of the reasons leading to new firm foundation across country and gender", Journal of Business Venturing, Vol. 6 No. 6, pp. 431-446. 
Shaw, E., Carter, S., Brierton, J. (2001), Unequal entrepreneurs: why female enterprise is an uphill business, Policy Paper, The Industrial Society, London.

Shaw, E. and Carter, S. (2007), "Social Entrepreneurship: Theoretical and empirical analysis of entrepreneurial processes and outcomes”, Journal of Small Business and Enterprise Development, Vol. 14 No. 3, pp. 418-434.

Shrivastava, P. (1994), “Castrated environment: greening organization studies. Organization studies, Vol.15 No.5, pp. 701-720.

Slovic P. (2000), The perception of risk, London, Earthscan Publications.

Stoner, C.R., Hartman, R.I., and Arora, R. (1990), "Work-home role conflict in female owners of small businesses: An exploratory study", Journal of Small Business Management, Vol. 28 No.1, pp. 30-38.

The European Commission Observatory of European SMEs (2003), SMEs and access to finance, No.2, Brussels.

Thompson, N., Kiefer, K. and York J.G. (2011), "Distinctions not Dichotomies: Exploring Social, Sustainable, and Environmental Entrepreneurship", in Lumpkin, G.T. and Katz, J.A. (Eds.), Social and Sustainable Entrepreneurship (Advances in Entrepreneurship, Firm Emergence and Growth, Volume 13), Howard House (UK): Emerald Publishing Limited, pp. 205-233.

Wilson, F., Marlino, D. and Kickul, J. (2004), “Our entrepreneurial future: Examining the diverse attitudes and motivations of teens across gender and ethnic identity", Journal of Developmental Entrepreneurship, Vol. 9 No. 3, pp. 177-197. 
World Commission on Environment and Development (1987), Our Common Future, Oxford, Oxford University Press. 